\title{
Teacher Psychological Needs, Locus of Control and Engagement
}

\author{
Fernando Doménech Betoret
}

Universitat Jaume I (Spain)

\begin{abstract}
This study examines the relationships among psychological needs, locus of control and engagement in a sample of 282 Spanish secondary school teachers. Nine teacher needs were identified based on the study of Bess (1977) and on the Self-Determination Theory (Deci \& Ryan, 1985, 2000, 2002). Self-report questionnaires were used to measure the construct selected for this study and their interrelationships were examined by conducting hierarchical regression analyses. An analysis of teacher responses using hierarchical regression reveals that psychological needs have significant positive effects on the three engagement dimensions (vigor, dedication and absorption). Furthermore, the results show the moderator role played by locus of control in the relationship between teacher psychological needs and the so-called core of engagement (vigor and dedication). Finally, practical implications are discussed.
\end{abstract}

Received 29 November 2011; Revised 27 March 2012; Accepted 24 May 2012

Keywords: teacher needs, locus of control, engagement, secondary school teachers.

Burnout and engagement have been considered the major indicators of workers' well-being. Most of the studies carried out in the past on workers' well-being have centered on the negative pole (burnout). Yet as a result of a resurge in positive psychology, the studies conducted in the last decade have increasingly addressed the positive pole; that is, work engagement (Seligman \& Csikszentmihalyi, 2000). However, research works focusing on investigating the relationship between teacher needs and work engagement are scarce (most are based on the Self-Determination Theory of Deci \& Ryan, 1985, 2000, 2002), but are very important for understanding the role played by psychological needs on teacher engagement and given the practical implications that may be derived to improve teacher well-being.

\section{Psychological needs}

The theories of Maslow (1954) and Herzberg (1966) are considered classic for explaining people's motivation. Maslow's theory (1954) proposes five categories of needs which are organized hierarchically to distinguish between lower-order needs and higher-order needs. These needs, arranged from lower to higher, are as follows: physiological, safety, love and belonging, esteem and self-actualization. According to Maslow, people's behavior aims to satisfy these basic, universal needs. Based on Maslow's needs theory (1954, 1972),

Correspondence concerning this article should be addressed to Fernando Doménech Betoret. Departamento de Psicología Evolutiva, Educativa, Social i Metodología. Universitat Jaume I. Campus Riu Sec. 12071 Castellón (Spain) Phone: +34-964729550. Fax: +34-964729262.

E-mail: betoret@psi.uji.es
Bess (1977) identifies seven needs related to teacher motivation whose dissatisfaction could diminish or negatively affect their motivation: utility, security, belongingness, self-development, achievement, competency and self-realization. Herzberg's theory (1966) presents two categories of the motives that influence people's attitudes to their work. One category is composed of the so-called "hygiene factors" or dissatisfiers: company policy, supervision, interpersonal relationship, work conditions and salary. Absence of these factors can lead to dissatisfaction at work, but their presence neither motivates nor produces satisfaction. The other category is made up of the factors known as "motivators", or satisfiers, which determine workers' motivation and satisfaction. "Satisfiers" reflect the relationship between the person and the task that he/she is doing, whereas "hygiene factors", or dissatisfiers, reflect the relationship between the person and the context.

Both classic theories share common features with another more recent motivational theory known as the Self-Determination Theory (SDT) (Deci \& Ryan, 1985, 2000, 2002). According to Deci and Ryan (1985, 2000, 2002), the SDT is an organism-based theory of optimal human motivation which, over the last three decades, has been extensively supported by a number of studies (Reis, Sheldon, Gable, Roscoe, \& Ryan, 2000; Sheldon, Elliot, Kim, \& Kasser, 2001; Sheldon, Ryan, \& Reis, 1996). According to the SDT, three basic psychological needs (autonomy, competence, and relatedness) undermine or support peoples' intrinsic motivation to engage in a given behavior. Autonomy occurs when people feel they are the cause of their behavior (Deci \& Ryan, 1985). "Autonomy is not independence or total freedom, rather an internal acceptance of, and engagement with, 
one's motivated behavior. Supporting autonomy means taking the student's perspective, offering choice, and providing a meaningful rationale when choice is not possible" (Filak \& Sheldon, 2003, p. 235). Competence occurs when one feels effective in one's behavior. Competence comes close to self-efficacy and can be seen when one undertakes and masters challenging tasks. "Relatedness occurs when one feels connected to, or understood by, others". This construct is similar to the need for belongingness posited by Baumeister and Leary (1995), but is more general and includes interpersonal and group connections (Filak \& Sheldon, 2003). According to the SDT, when these three needs are satisfied, they encourage psychological well-being and employees' intrinsic motivation which, in turn, leads to effective performance (Gagné \& Deci, 2005). Recent studies have shown that school teachers, more than any other professionals, suffer lack of work motivation (Jesus \& Lens, 2005), and motivation is crucial for optimal human functioning in the workplace (Fernet, Senecal, Guay, Marsh, \& Dowson, 2008).

Given that Bess' (1977) theory is centered specifically on teachers needs and the Self-Determination Theory (Deci \& Ryan, 1985, 2000, 2002) focuses on employees or workers in general, we thought that the three basic needs of the SDT could also be considered basic needs for teachers and could complement the more specific proposal made by Bess (1977)

\section{Work engagement}

Promoting employees positive psychological states (such as engagement) is very important for organizations. Recent studies have shown the benefits of engagement on workers behaviors and attitudes which, in turn, will have a positive effect on the organization. For example, the results have revealed that work engagement is positively related to in-role and extra-role performance (Halbesleben \& Wheeler, 2008; Schaufeli, Taris, \& Bakker, 2006) and client satisfaction (Salanova, Agut, \& Peiró, 2005).

Previous research (Schaufeli, Salanova, GonzálezRomá, \& Bakker, 2002) has verified that although work engagement is considered the opposite concept of burnout, it has a different structure. From this point of view, work engagement is defined as "a positive, fulfilling, work-related state of mind characterized by vigor, dedication and absorption" (Schaufeli et al., 2002, p. 74). Vigor refers to high levels of energy and mental resilience at work. Dedication is characterized by being deeply involved at work, and experiencing a sense of significance, enthusiasm and pride. Absorption is characterized by being fully concentrated and happy at work. In the present study, we have followed the conceptualization proposed by Schaufeli et al. (2002). The Utrecht
Work Engagement Scale (UWES) (Schaufeli \& Bakker, 2003; Schaufeli et al., 2002) was created to measure the three components of engagement (vigor, dedication and absorption) according to this perspective.

\section{Teacher Psychological Needs and Well-being}

Teacher psychological needs are considered to play an important role in the study of teacher professional health and well-being. The Job Demands and Resources Model of work engagement (JD-R) (Bakker \& Demerouti, 2007 , 2008) highlights/emphasizes the importance of job resources to predict engagement. According to this proposal, job demands versus resources drive two different yet related processes: an energetic process in which high job demands may lead to burnout; a motivational process in which job resources promote engagement and organizational commitment (Schaufeli \& Bakker, 2004). According to the JD-R model, the reason for the motivational process is the motivational role played by job resources, which may be intrinsic or extrinsic. The intrinsic role played by job resources can be explained by the Self-Determination Theory (SDT) (Deci \& Ryan, $1985,2000,2002)$ since any social context that satisfies psychological human needs (e.g., autonomy, competence and relatedness) enhances well-being and increases commitment (Hackman \& Oldham, 1980; van den Broeck, Vansteenkiste, De Witte, \& Lens, 2008). In light of this, it is plausible to assume that the link between job resources and engagement may be mediated by human needs. If so, psychological needs would have a direct effect on work engagement, whereas job resources would have an indirect effect through psychological needs, which means that needs would probably be better predictors of work engagement than job resources.

Previous research has verified the relationship between employees' needs and professional well-being. In their study, Gold and Roth (2005) examined the relationship between teacher needs and professional health. They came to the conclusion that "When an individual perceives that their needs are not met over a period of time, they become discouraged, angry and depressed" (Gold \& Roth, 2005, p. 42). These authors classified needs into three broad categories (emotional-physical needs, psycho-social needs and personal-intellectual needs). They highlighted the importance of the so-called socio-psychological needs, such as interaction and support from other colleagues, which are considered the underlying causes of teacher stress and burnout (Gold \& Roth, 2005). Other studies have proved that satisfying psychological needs is significantly and positively related with components of engagement (vigor), but is significantly and negatively related with components of burnout (emotional exhaustion) (see van den Broeck et al., 2008). Therefore, it seems that unmet or 
unsatisfied psychological needs provoke negative consequences in human beings, which may affect their health and efficacy at work. Conversely, satisfying these needs is associated with more effective performance and well-being (Deci \& Ryan, 1985, 2000). Accordingly, in order to improve teacher well-being, support and opportunities to meet teacher needs must be provided through professional health programs (Gold \& Roth, 2005).

\section{Locus of Control and Well-being}

The Job Demands and Resources Model of work engagement (JD-R) (Bakker \& Demerouti, 2007, 2008) proposes that personal resources, either independently or combined with job resources, also predict work engagement. According to the JD-R, personal resources not only refer to positive self-evaluations associated with resiliency, but indicate the individual sense of one's ability to control and impact the environment successfully (Hobfoll, Jonson, Ennis, \& Jackson, 2003). Previous studies have shown that personal resources consistently influence psychological well-being (Lorente, Salanova, Martínez, \& Schaufeli, 2008; Xanthopoulou, Bakker, Demerouti, \& Schaufeli, 2007). Accordingly, and based on the JD-R proposal, locus of control has been selected as a personal resource since this variable is considered a personal resource related with subjects' capacity to control their environment.

The locus of control concept was developed by Rotter in 1954. Locus of control refers to the extent to which individuals believe they can control the events affecting them. Subjects with a high internal locus of control believe that events result primarily from their own behavior and actions. Conversely, subjects with a high external locus of control believe that powerful others, such as fate, chance, etc., primarily determine events. Internal control beliefs are an important key of emotional adjustment and ability to handle stress at work (Spector, 1982) and also in general life (e.g., Kobasa, Maddi, \& Kahn, 1982).

Evidence reported from previous studies suggests that locus of control in the workplace has been linked to employee well-being (Ganster \& Fusilier, 1999; Spector, 1988; Spector, Cooper, Sanchez, O'Driscoll, \& Sparks, 2002; Spector \& O'Connell, 1994). According to Spector et al. (2002), locus of control was perhaps the most studied control-related variable. Locus of control in the workplace, understood as beliefs that one has control at work, has been linked to employee well-being (e.g., Spector 1988; Spector \& O'Gonnell, 1994). Moreover, the study conducted by Spector et al. (2002) indicates on the one hand that "Research support the notion that internality is associated with positive well-being both on and off the job" (p. 454). On the other hand, it is believed that locus of control contributes to well-being universally since the findings reached were similar in almost all the sampled areas. Moreover, Scott, Cox, and Dinham (1999), found that teachers were more satisfied if they had greater control over their work. Similarly, Stockard and Lehman (2004) discovered that satisfaction was significantly influenced by the level of control that teachers had over the work environment. The study conducted by Näring, Briet, and Brouwers (2006) with secondary school teachers from the Netherlands showed that greater job control was positively related to perceptions of personal accomplishment. In a longitudinal research study with a large sample of Human Service Employees in Sweden, van Vegchel, De Jonge, Soderfeldt, Dormann, and Schaufeli (2004) found that job control was linked to emotional demands and emotional exhaustion. Similarly, there has been evidence that those teachers with high external control are more likely to suffer burnout (Farber, 1991; Kyriacou, 1987; Rotter, 1966). In short, research supports the notion that job control or internal locus of control is associated with positive well-being both on and off the job, whereas external locus of control is associated with negative health consequences.

As the present study deals with teacher needs, we are interested in knowing the level of control that teachers perceive they have on all nine needs identified and how this controllability may affect teacher engagement. That is, firstly we wish to know, and to what extent, if teachers believe that the fulfillment of the nine needs considered primarily results from their own behavior and actions or if, conversely, they believe that the fulfillment of their needs is primarily determined by powerful others, such as fate, chance, etc. Secondly, we want to examine the moderator role played by locus of control in the relationship between psychological needs and teacher engagement. Previous studies have found that satisfaction of psychological needs encourages employees' well-being and intrinsic motivation (Gagné \& Deci, 2005), and also that job control is related to motivation (Demerouti, Bakker, Janssen, \& Schaufeli, 2001). Therefore, it is reasonable to think that teacher motivation and engagement could be influenced by the satisfaction of their professional needs and by some personal variables such as locus of need job control. So, we thought it could be interesting to explore the interaction between psychological needs in the workplace (work environment) and the locus of need control perceived by teachers (personal variable). Specifically, we want to know to what extent locus of control moderate the relationship between psychological needs and teacher engagement. It could be expected that teachers who thinkhat their professional needs are generally under control, probably they will feel more motivated and engaged in the workplace 
than those teachers who believe that nothing can be done to fulfill their professional needs. Teachers who believe that professional needs are beyond their control, probably will experience a feeling of impotence that may negatively affect their engagement at work.

\section{Objectives}

Based on the aforementioned considerations, the objectives of this work are: firstly, to examine the predictive capacity of teacher psychological needs in teacher engagement. We hypothesize that teacher psychological needs will positively predict teacher engagement; secondly, to examine the moderator role of locus of control on teacher psychological needs in the relationship between psychological needs and engagement in the teaching profession. We hypothesize that locus of control on needs will play a moderator role between teacher psychological needs and engagement. That is, the greater the degree of control that teachers perceive to have on their psychological needs, the more engaged they are at work; and vice versa, the lower the degree of control teachers perceive to have on their psychological needs, the less engaged they are.

\section{Method}

\section{Participants and Procedure}

A total sample of 282 Spanish secondary school teachers participated in this study. In gender terms, the sample consisted in 276 valid cases (124 males, 44.9\% and 152 females, $55.1 \%$ ) from 23 schools (19 public and 4 private) in Eastern Spain. Teachers were aged between 20 and 60 years $(M=38.6, S D=9.20)$ and their professional experience ranged between 1 and 39 years $(M=15.33$, $S D=8.86$ ).

Schools were randomly selected from public and private schools. After selecting the schools, a presentation letter was sent to the school to inform about the research aims and to request its participation. Then an interview was requested with the school headmaster to offer verbal information about the research, to clarify doubts and to request permission to interview schoolteachers. Those teachers who agreed to participate were given a battery of questionnaires inside an envelope. Instructions were also given as to filling in the questionnaires and sending them back. All the questionnaires handed out were completed anonymously and participation in this study was entirely voluntary. The response rate was $58 \%$.

\section{Measuring Instruments}

Teacher psychological needs scale (TPNS). This scale was constructed based on the seven teaching needs proposed by Bess (1977) and the three needs proposed by the Self-Determination Theory (SDT) (Deci \& Ryan, $1985,2000,2002)$. The initial scale was composed of 43 items to assess 10 needs. All the teachers' responses scored on a four-point Likert scale, with the following response options: 1 (I quite disagree), 2 (I disagree more than I agree), 3 (I agree more than I disagree), 4 (I quite agree)". A preliminary and exploratory factor analysis (EFA) was conducted on the whole scale to check the structure of the scale by means of the principal components method with varimax rotation. The preliminary EFA suggests that 7 items had either low (below .3) or substantial loadings (over .3) on more than one factor. Therefore, they were removed in order to clarify the construct interpretation. A further EFA was conducted on the remaining 36 items of the scale. Nine factors were extracted with eigenvalues exceeding unity. The factor solution accounted for $68.16 \%$ of total variance. In general, Cronbach's coefficient alpha reliabilities were good for all the subscales (except for F9, which scored .56), the index of which ranged from .72 (minimum) to .90 (maximum). The extracted factors and an example of an item included in each factor are as follows: (a) Factor 1 (Relatedness-belonging, $\alpha=.89$ ): "In this department, I feel that I belong to one big family", (b) Factor 2 (Utility, $\alpha=.89$ ): "I think that what I teach students will be useful for their own personal life"; (c) Factor 3 (Security, $\alpha=.90$ ): "Practicing my profession is not a risk for my personal security"; (d) Factor 4 (Recognition, $\alpha=.85$ ): "Students' parents do not appreciate our work"; (e) Factor 5 (Autonomy, $\alpha=0.76)$ : "I am free to decide how and what I teach in my classes"; (f) Factor 6 (Professional development, $\alpha=$ .72): "My profession offers me the possibility of developing professionally"; g) Factor 7 (Self-realization, $\alpha=$ .74): "I feel fulfilled by practicing my profession"; (h) Factor 8 (Competency, $\alpha=.72$ ): "I believe I am a competent enough teacher to be teaching students in the 21st century"; (i) Factor 9 (Achievement/results, $\alpha=.56$ ): "I usually meet the objectives set out in my course subject(s) for each academic year". As seen, the nine factors extracted corresponding to nine teacher needs (relatedness and belongingness, initially separated were combined in Factor 1: need of relatedness-belongingness (1), need of utility (2), need of security (3), need of social recognition (4), need of autonomy (5), need of professional development (6), need of self-realization (7), need of competency (8) and need of achievement/ results (9). Negative items were reversed coded and measures were constructed by averaging the items on each factor.

Subsequently, a Confirmatory Factor Analysis (CFA) was conducted to verify the factorial structure of the measurement model obtained with the EFA. The nine-factor structure of the model was then tested for its goodness-of-fit using the maximum likelihood 
estimation procedure with EQS (Bentler, 2006). The covariance between the factors and the errors between the observational variables inside each factor or subscale were introduced because of their intercorrelations. The indices obtained were the following: $(n=273$ valid cases): $\chi^{2}=862.90$ based on $519 \mathrm{df}, p=.001$; Bentler-Bonett Non Normed Fit Index $(B N N F I)=.914$; Comparative Fit Index (CFI) = .929; and Root MeanSquare Error of Approximation (RMSEA) $=.049(90 \%$ CI: .043, .055). The indices show a good fit of the model to the empirical data, thus supporting the nine-factor structure.

\section{Locus of Need Control Scale}

This scale, composed of 10 items, has been devised for this study to assess the degree of locus of control that teachers perceive they have in order to meet the nine identified psychological needs. Teachers were asked the following question: "To what extend does it depends on you to fulfill the basic teaching needs listed below? Examples of items are: "Need of feeling efficacy at work (need of competency)", Need of achieving learning objectives (need of achievement)", "Need of a relationship with co-workers (need of relatedness)", "Need of being safe at work (need of safety)", "Need of being valued by society (need of social recognition)", etc. Items were measured with a 4-point Likert-type scale whose answers ranged between "It depends totally on me" (4), "It depends quite a lot on me" (3), "It somewhat depends on me" (2), "It does not depends on me" (4). The scale was found to have good psychometric properties, with Cronbach's alpha $=.81$. A general measure was obtained for all the scale by calculating the average of the scores obtained with the whole scale.

\section{Work Engagement Scale}

The three aspects of work engagement (vigor, dedication and absorption) were assessed using a Spanish translated version of the Utrecht Work Engagement Scale (UWES) (Schaufeli \& Bakker, 2003; Schaufeli et al., 2002). This scale is made up of 17 items and three components: vigor (6 items), dedication (5 items) and absorption (6 items). It was found to have good psychometric properties, with Cronbach's alpha generally higher than .80 (Durán, Extremera, \& Rey, 2004; Schaufeli \& Bakker, 2004). Moreover, the CFA showed that a three-factor scale structure (vigor, dedication, absorption) was superior in terms of fit to a one-factor structure (Engagement) (Schaufeli et al., 2002). In line with previous research, the scale presented also shows good internal consistency for the present study ( $\alpha=.82$ for vigor; $\alpha=.88$ for dedication; $\alpha=.74$ for absorption).

\section{Data analysis}

To accomplish the objectives set out, descriptive and internal consistency analyses were done of the scales, and the bivariate correlations among the variables were considered. Subsequently, a hierarchical multiple regression analysis was carried out for all the dimensions of engagement (vigor, dedication and absorption), taken as dependent variables. The independent variables were introduced into the regression equation in four successive steps; previously, however, they were standardized to minimize multicolinearity following the recommendations of Aiken and West (1991). In the first step, demographic variables were introduced (gender and professional experience) to control their possible influence. In the second step, teacher psychological needs were introduced as independent variables to determine their impact on engagement. In the third step, locus of control of all the psychological needs was introduced to determine their impact on engagement. In the fourth and final step, the interactions between psychological needs and locus of control were introduced (teacher psychological needs $\times$ locus of control of each psychological need).

\section{Results}

\section{Descriptive Analyses and Correlations among Variables}

Table 1 shows the factors, means, standard deviations and alpha coefficients for the scales used. In general, the scales present good internal consistency indices which range between .72 and .90 , except achievement/ results which has a lower value (.56). Table 1 also displays Pearson's bivariate correlations among the variables, which follow the expected direction. Overall, the data show that the psychological needs correlate positively and significantly with locus of control and the three dimensions of engagement (vigor, dedication and absorption). Moreover, locus of control correlates positively and significantly with the three dimensions of engagement. For more details, see Table 1.

\section{Regression Analysis}

Three sets of hierarchical multiple regression analyses were performed to determine the main effects of psychological needs and the effects of the interaction between psychological needs and locus of control on the three dimensions of engagement.

Table 2 displays the results of the regression analysis in which vigor is considered a dependent variable. These results reveal the main effects of teacher psychological needs and locus of control. As seen, some psychological needs significantly predict vigor (N2: utility, $t=2.45, p<.05 ;$ N5: autonomy, $t=2.48 ; p<.05 ;$ 


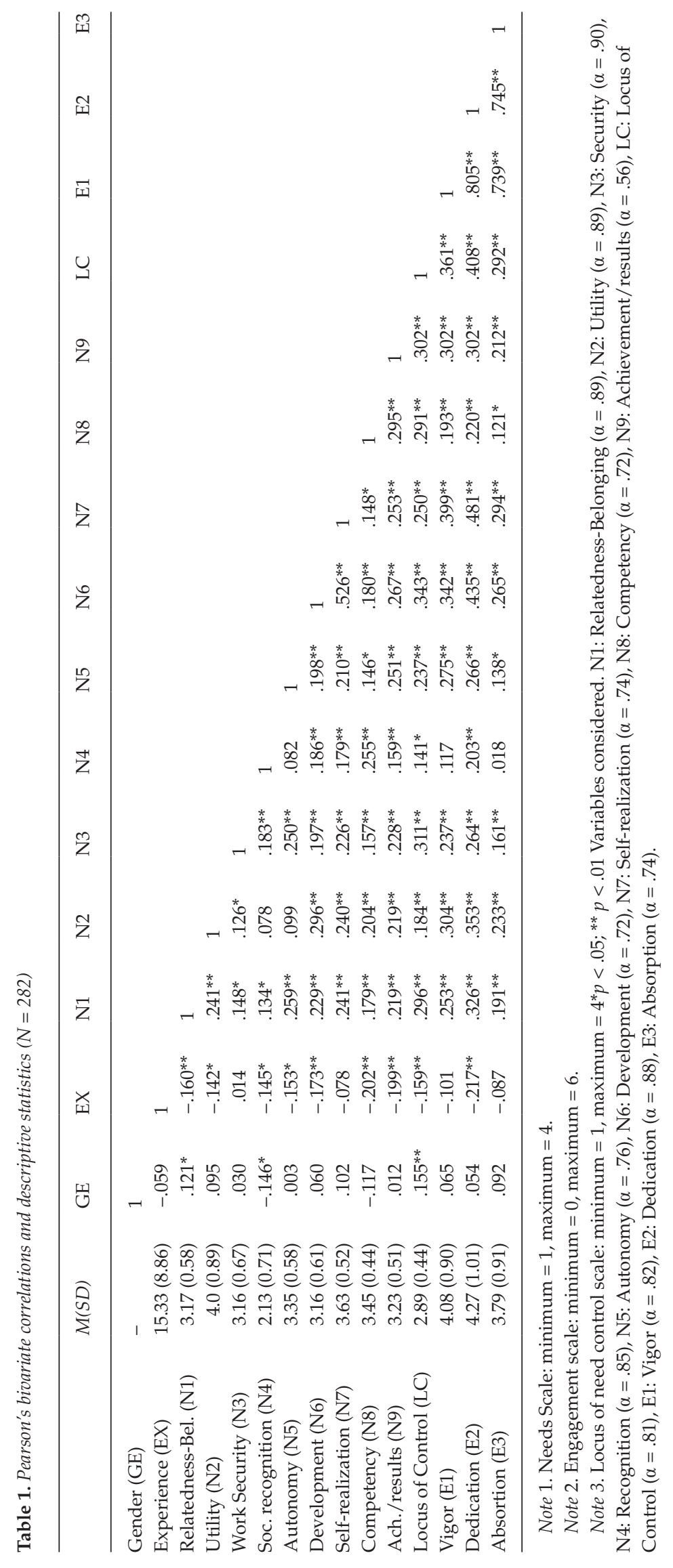


Table 2. Hierarchical multiple regression analysis $(N=282)$. Dependent variable: Vigor (E1)

\begin{tabular}{|c|c|c|c|c|}
\hline Independent variables & Beta & $t$ & $R^{2}$ & Change $R^{2}$ \\
\hline Step 1 (Biographical variables) & & & 0.021 & 0.021 \\
\hline Gender & 0.02 & 0.39 & & \\
\hline Experience & -0.10 & -1.72 & & \\
\hline Step 2 (Psychological needs) & & & 0.280 & $9.94^{* * *}$ \\
\hline N1. Relatedness/Belonging & 0.04 & 0.80 & & \\
\hline N2. Utility & 0.14 & $2.45^{*}$ & & \\
\hline N3. Work Security & 0.08 & 1.42 & & \\
\hline N4. Social Recognition & 0.04 & 0.06 & & \\
\hline N5. Autonomy & 0.14 & $2.48^{*}$ & & \\
\hline N6. Professional Development & 0.10 & 1,58 & & \\
\hline N7. Self-realization & 0.19 & $3.02^{* *}$ & & \\
\hline N8. Competency & 0.05 & 0.94 & & \\
\hline N9. Achievement/Results & 0.12 & $2.06^{*}$ & & \\
\hline Step 3 (Locus of control) & & & 0.300 & $0.020^{* *}$ \\
\hline Locus of Control & 0.16 & $2.65^{* *}$ & & \\
\hline Step 4 (Psychological needs $\times$ locus of control ) & & & 0.351 & $0.051^{*}$ \\
\hline N1. Relatedness-Belong. $\times$ locus of control & 2,26 & $2.03^{*}$ & & \\
\hline N2. Utility $\times$ locus of control & 0.21 & $1.95^{*}$ & & \\
\hline N3. Work Security $\times$ locus of control & 0.33 & $2.92^{* *}$ & & \\
\hline N4. Social Recognition $\times$ locus of control & 0.06 & 0.50 & & \\
\hline N5. Autonomy $\times$ locus of control & 0.01 & 0.10 & & \\
\hline N6. Professional Development $\times$ locus of control & 0.38 & $2.78^{* *}$ & & \\
\hline N7. Self-realization $\times$ locus of control & 0.06 & 0.58 & & \\
\hline N8. Competency $\times$ locus of control & 0.08 & 0.72 & & \\
\hline N9. Achievement/Results $\times$ locus of control & 0.19 & 1.65 & & \\
\hline
\end{tabular}

Note: ${ }^{*} p<.05 ;{ }^{* *} p<.01 ;{ }^{* * *} p<.001$.

N7: self-realization, $t=3.02, p<.01$ and N9: achievement/ results, $t=2.06, p<.05$ ), accounting for around $28 \%$ of the explained variance. Locus of need control also predicts vigor significantly, and accounts for around $2 \%$ of explained variance $(t=2.65, p<.05)$.

Regarding interaction effects, the results show that other than having a significant main effect, Locus of need control also moderate some of the relationships between psychological needs and vigor, as hypothesized (Change $\left.R^{2}=0.051, p<.05\right)$. For example, relatednessbelonging $x$ locus of control $(t=2.03, p<.05)$, security $x$ locus of control $(t=2.92 ; p<.01)$ and development $x$ locus of control $(t=2.78 ; p<.01)$.

Table 3 displays the results of the regression analysis in which dedication is considered a dependent variable. These results indicate that as teachers gain more experience, they perceive themselves as having less dedication at work $(t=-3.61 ; p<.001)$. Furthermore, the results also show the main effects of teacher psychological needs and locus of control. The primary psychological need that predicts dedication is self-realization $(t=$ $3.97, p<.001)$, followed by utility $(t=2.94 ; p<.01)$ and professional development $(t=2.55 ; p<.05)$, which accounts for around $32 \%$ of variance. Locus of need control has a positive and significant effect on dedication $(\mathrm{t}=3.32, p<.01)$ and explains $2.6 \%$ of variance.

Regarding interaction effects, the results show that other than having a significant main effect, locus of control also moderates some of the relationships between psychological need and dedication, as hypothesized

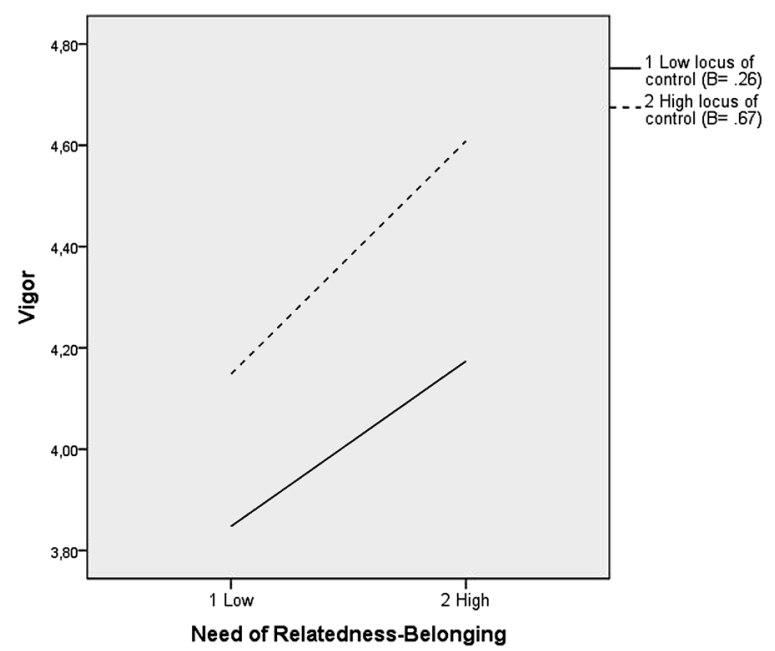

Figure 1. Interaction between need of relatedness-belonging $x$ locus of control. 


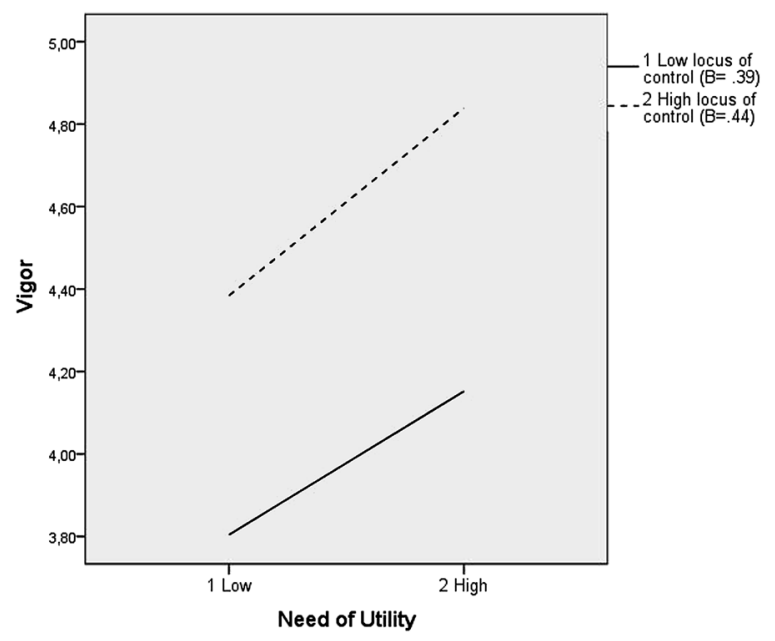

Figure 2. Interaction between need of utility $\times$ locus of control.

(Change $\left.R^{2}=0.055, p<.01\right)$. However, the only interaction to have a significant effect on dedication is professional development $\times$ locus of control $(t=2.05 ; p<.05)$.

Table 4 displays the results of the regression analysis in which absorption is considered a dependent variable. These results present the main effects of both teacher psychological needs and locus of control. As seen for psychological needs, only self-realization has a significant effect on absorption $(t=2.14 ; p<.05)$, which accounts for around $14 \%$ of explained variance. Locus of control has a positive and significant effect on absorption $(t=2.76 ; p<.01)$, which accounts for $2.5 \%$ of explained variance.

Regarding interaction effects, the results indicate that, conversely to what has been hypothesized, locus of control does not moderate the relationship between teacher psychological needs and absorption.

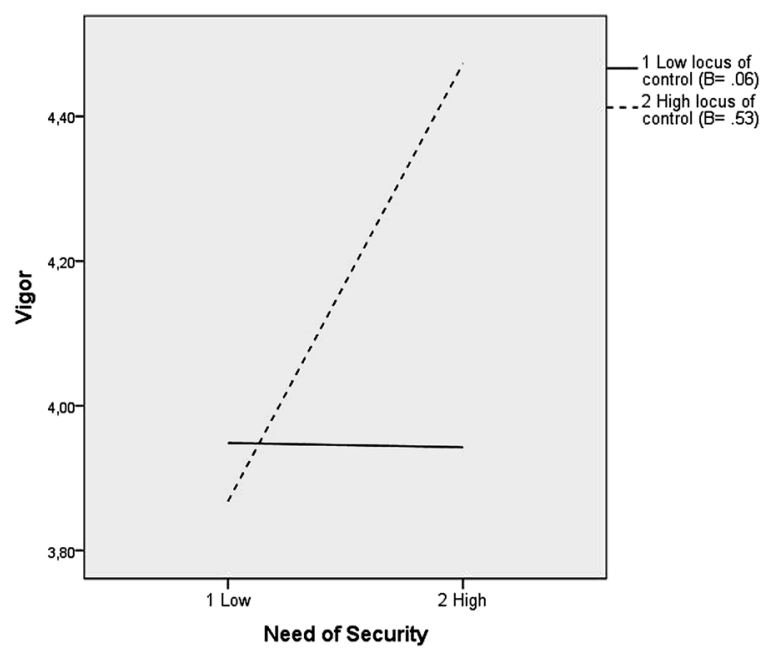

Figure 3. Interaction between need of security $\times$ locus of control.

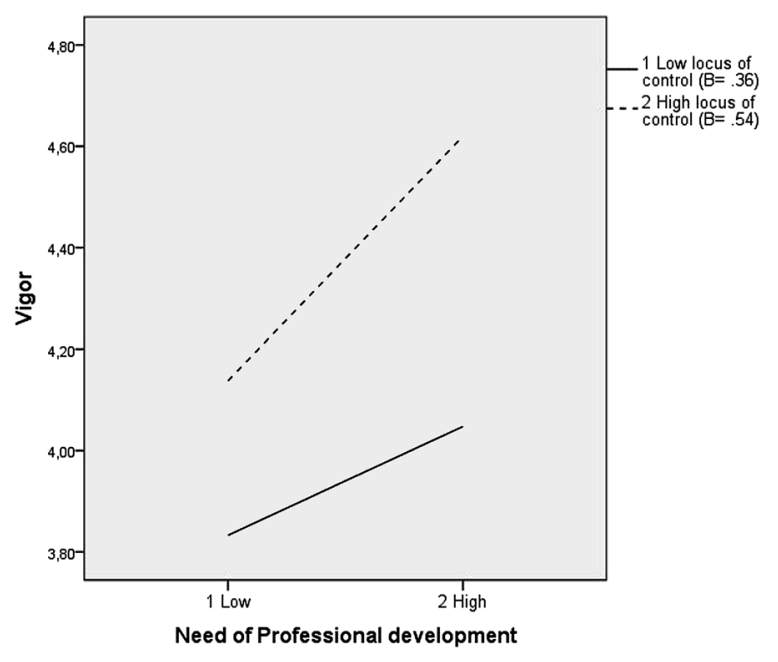

Figure 4. Interaction between need of professional development $\times$ locus of control.

\section{Discussion}

The relationships among psychological needs, locus of control and engagement in a sample of Spanish secondary school teachers are discussed.

The teacher psychological needs scale (TPNS), the main instrument employed in this study to assess the fulfillment of teacher psychological needs, shows good psychometric properties. The subscales present good internal consistencies, and they all (except achievement/ results) meet the standard of .70 recommended by Nunnaly and Berstein (1994). Only the achievement/ results scale shows low reliability, suggesting that it should be reviewed and reformulated in future research.

The first objective consisted in examining the predictive capacity of teacher psychological needs in teacher engagement. The results obtained from the hierarchical multiple regression analyses performed present positive and significant main effects of certain psychological needs on engagement dimensions, indicating that when satisfaction or fulfillment of certain teacher psychological needs increases, the level of teacher engagement also increases. Teacher self-realization (N7) is the factor with a better predictive capacity on the three teacher engagement dimensions: vigor, dedication and absorption. Utility (N2) is seen as a good predictor of vigor and dedication. Achievement/results (N9) and autonomy (N5) also emerge as significant predictors of vigor, while professional development (N6) is a significant predictor of dedication. Overall, these results follow the expected hypothesized pattern and reveal that the degree of fulfillment of certain teacher psychological needs is a good predictor of teaching engagement and explains a substantial percentage of variance for the three dimensions of 
Table 3. Hierarchical multiple regression analysis $(N=724)$. Dependent variable: Dedication (E2)

\begin{tabular}{|c|c|c|c|c|}
\hline Independent variables & Beta & $t$ & $R^{2}$ & Change $R^{2}$ \\
\hline Step 1 (Biographical variables) & & & 0.065 & $0.065^{* *}$ \\
\hline Gender & -0.07 & -0.19 & & \\
\hline Experience & -0.21 & $-3.61^{* * *}$ & & \\
\hline Step 2 (Psychological needs) & & & 0.381 & $0.316^{* * *}$ \\
\hline N1. Relatedness/Belonging & 0.10 & 1.90 & & \\
\hline N2. Utility & 0.16 & $2.94^{* *}$ & & \\
\hline N3. Work Security & 0.08 & 1.66 & & \\
\hline N4. Social Recognition & 0.06 & 1.18 & & \\
\hline N5. Autonomy & 0.90 & 1.66 & & \\
\hline N6. Professional Development & 0.58 & $2.55^{*}$ & & \\
\hline N7. Self-realization & 0.24 & $3.97^{* * *}$ & & \\
\hline N8. Competency & 0.03 & 0.53 & & \\
\hline N9. Achievement/Results & 0.58 & 1.03 & & \\
\hline Step 3 (Locus of control) & & & 0.407 & $0.026^{* *}$ \\
\hline Locus of Control & 0.19 & $3.32 * *$ & & \\
\hline Step 4 (Psychological needs $\times$ locus of control ) & & & 0.463 & $0.055^{* *}$ \\
\hline N1. Relatedness-Belong. $\times$ locus of control & 0.11 & 0.99 & & \\
\hline N2. Utility $\times$ locus of control & 0.17 & 1.73 & & \\
\hline N3. Work Security $\times$ locus of control & 0.13 & 1.28 & & \\
\hline N4. Social Recognition $\times$ locus of control & 0.08 & 0.64 & & \\
\hline N5. Autonomy $\times$ locus of control & -0.11 & -1.25 & & \\
\hline N6. Professional Development $\times$ locus of control & 0.25 & $2.05^{*}$ & & \\
\hline N7. Self-realization $\times$ locus of control & 0.08 & 0.75 & & \\
\hline N8. Competency $\times$ locus of control & 0.25 & 0.24 & & \\
\hline N9. Achievement/Results $\times$ locus of control & -0.02 & -0.24 & & \\
\hline
\end{tabular}

Note: ${ }^{*} p<.05 ;{ }^{* *} p<.01 ;{ }^{* * *} p<.001$.

engagement (around 26\% for vigor, around 32\% for dedication, and about $14 \%$ for absorption). These results reveal that teacher psychological needs are good predictors of engagement, especially of the so-called core of engagement, formed by vigor and dedication (Schaufeli et al., 2002). In line with previous studies

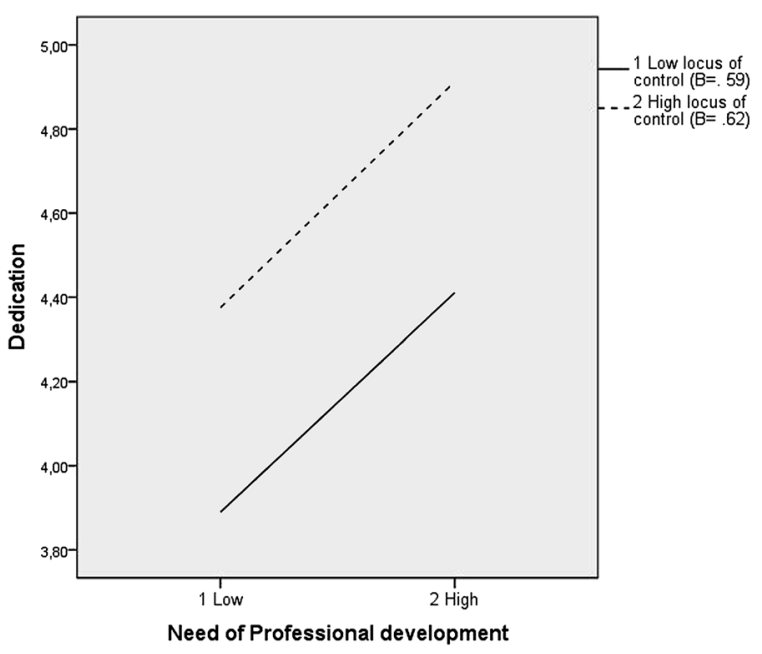

Figure 5. Interaction between need of professional development $\times$ locus of control.
(Deci \& Ryan, 1985, 2000; van den Broeck et al., 2008), the data obtained suggest that met or satisfied teachers psychological needs may affect their engagement with all the positive implications it may have at work. In this sense, the Self-Determination Theory (SDT) (Deci \& Ryan, 1985, 2000, 2002) suggests that satisfaction of the three basic psychological needs (autonomy, competence and relatedness) enhances employees' intrinsic motivation and that this, in turn, yields important outcomes, such as "effective performance, particularly in tasks requiring creativity, cognitive flexibility, and conceptual understanding" (Gagné \& Deci, 2005, p. 337). In sum, from our results we can assert that the data obtained support the hypothesized relationship between teacher psychological needs and engagement.

The second objective consisted in analyzing whether locus of control moderates the relationship between teacher psychological needs and engagement. Regarding the moderator role played between teacher needs and vigor (E1), the results obtained, and described in the Results section, reveal that the control perceived by teachers of all the psychological needs considered moderates the relationship between several psychological needs and vigor $\left(R^{2}=.35\right)$. For instance, interactions such as work security $\times$ locus of control, professional 
Table 4. Hierarchical multiple regression analysis $(N=282)$. Dependent variable: Absorption (E3)

\begin{tabular}{|c|c|c|c|c|}
\hline Independent variables & Beta & $t$ & $R^{2}$ & Change $R^{2}$ \\
\hline Step 1 (Biographical variables) & & & 0.019 & 0.019 \\
\hline Gender & 0.06 & 1.03 & & \\
\hline Experience & -0.08 & -1.43 & & \\
\hline Step 2 (Psychological needs) & & & 0.155 & $0.136^{* * *}$ \\
\hline N1. Relatedness/Belonging & 0.06 & 1.00 & & \\
\hline N2. Utility & 0.10 & 1.64 & & \\
\hline N3. Work Security & 0.06 & 0.98 & & \\
\hline N4. Social Recognition & -0.06 & -1.06 & & \\
\hline N5. Autonomy & 0.03 & 0.55 & & \\
\hline N6. Professional Development & 0.11 & 1.59 & & \\
\hline N7. Self-realization & 1.15 & $2.14^{*}$ & & \\
\hline N8. Competency & 0.04 & 0.68 & & \\
\hline N9. Achievement/Results & 0.08 & 1.21 & & \\
\hline Step 3 (Locus of control) & & & 0.180 & $0.025^{* *}$ \\
\hline Locus of Control & 0.18 & $2.76^{* *}$ & & \\
\hline Step 4 (Psychological needs $\times$ locus of control ) & & & 0.219 & 0.039 \\
\hline N1. Relatedness-Belong. $\times$ locus of control & 0.15 & 1.08 & & \\
\hline N2. Utility $\times$ locus of control & 0.17 & 1.44 & & \\
\hline N3. Work Security $\times$ locus of control & 0.20 & 1.59 & & \\
\hline N4. Social Recognition $\times$ locus of control & 0.18 & 1.25 & & \\
\hline N5. Autonomy $\times$ locus of control & -0.02 & -0.24 & & \\
\hline N6. Professional Development $\times$ locus of control & 0.25 & 1.73 & & \\
\hline N7. Self-realization $\times$ locus of control & 0.11 & 0.84 & & \\
\hline N8. Competency $\times$ locus of control & 0.23 & 1.92 & & \\
\hline N9. Achievement/Results $\times$ locus of control & 0.11 & 0.87 & & \\
\hline
\end{tabular}

Note: ${ }^{*}<.05 ;{ }^{* *} p<.01 ;{ }^{* * *} p<.001$.

development $\times$ locus of control, relatedness- belonging $\times$ locus of control, and finally utility $\times$ locus of control have a significant and positive effect on vigor. The data suggest that good control on work security, sound control on professional development, good control on relatedness- belonging and high control on utility increase teachers' vigor in the workplace; that is, their level of energy and mental resilience. Conversely, teachers who believe that "There's nothing they can do" toward security at work, professional development, relatedness, or for more utility, display lower levels of energy and mental resilience. Overall, these results suggest that when teachers perceive they have more control over their psychological needs, they work more energetically and display a positive capacity to cope with stress and adversity. According to these results, we can assert that locus of control moderates the relationship between teacher needs and vigor. Therefore, the data obtained support the hypothesized moderation role played by locus of control in the relationship between psychological needs and vigor (one of the components of engagement).

Regarding the moderator role played between teacher needs and dedication (E2), locus of control also moderates the relationship between psychological needs and dedication $\left(R^{2}=.46\right)$. Yet only the professional development $x$ locus of control interaction has a significant and positive effect on dedication. These results reveal that when teachers perceive they have more control over needs, professional development increases teacher dedication. These data suggest that the teachers who believe that their professional development depends mainly on their own behavior and actions are strongly involved at work, and experience a sense of significance, enthusiasm and pride. Conversely, those teachers who believe that "There's nothing they can do" toward their professional development are little involved at work. According to these results, we can assert that locus of control moderates the relationship between teacher needs and dedication. Therefore, the data obtained support the hypothesized moderation role played by locus of control in the relationship between psychological needs and dedication (one of the components of engagement).

As regards the moderator role played between teacher needs and absorption (E3), this study has not verified whether locus of control moderates the relationship between teacher psychological needs and absorption since the change of the coefficient of determination (Change $R^{2}$ ) was not significant for this dimension. 
These results suggest that absorption, characterized by being fully concentrated and happy at work, does not depend on the control perceived by teachers of their psychological needs considered in this study. According to these results, we rejected the hypothesized moderation role played by locus of control in the relationship between psychological needs and absorption (one of the components of engagement).

In sum, the results obtained for the second objective largely verify the moderator role played by locus of control in the relationship between teacher needs and vigor (E1), and in the relationship between teacher needs and dedication, but to a lesser extent (E2). Both components are named the core of engagement (Schaufeli et al., 2002). Therefore, we can conclude that locus of control plays a moderator role in the relationship between teacher needs and the core of engagement, especially locus of professional development need of control. It is important to emphasize that the moderator role played by locus of psychological need control is more or less stronger depending on the type of need. This is perhaps because teachers consider that having control on some specific needs (such as professional development) is more important than others to be engaged. More research is needed to know why certain needs were related to interactions while others were not.

Finally we note that, although the studies conducted in this field are very limited, these results are in the same direction as those obtained in similar studies with other professions. Former reported evidence suggests that locus of control in the workplace is linked to employee wellbeing (Spector, 1988; Spector \& O'Connell, 1994).

Among the main limitations of this work we find the exclusive use of self-reporting techniques to collect information. Experts recommend combining this type of measuring instruments with other more qualitative ones as they argue that the responses to the questionnaire may be influenced by personal or social values. The second main limitation is the representativeness of the study sample. Note that the teachers participated voluntarily in this study, so there was no random selection involved to ensure that the sample was representative of the population. Therefore, caution is needed when generalizing these results. The third major limitation is the low reliability obtained in the achievement/ results need subscale. Finally, the forth major limitation refers to this study's cross-sectional design, which prevents acquiring information over time as well as interpreting the relationship obtained in terms of causality.

\section{Practical Implications}

Despite these limitations, this study provides new data to previous research into the field of teacher well-being.
Apart from contributing to the understanding of this phenomenon, this work also presents practical implications to reduce teacher burnout. Regarding teacher psychological needs, developing a positive work climate at school to satisfy teacher needs would firstly be recommendable. According to the Self-Determination Theory (Deci \& Ryan, 1985, 2000, 2002), any social context that satisfies basic psychological human needs (such as autonomy, competence and relatedness) enhances well-being and increases commitment (see also Hackman \& Oldham, 1980). Accordingly, support and opportunities to meet teacher needs must be provided to improve teacher engagement and well-being (Gold \& Roth, 2005).

Concerning locus of control, attempts to change teacher beliefs and their ways of thinking about the controllability of their needs would also be necessary. Changing teacher beliefs by showing them that they may contribute, to a certain extent, to their own attitudes and behavior to fulfill most of their psychological needs is recommendable. Changing teachers' way of thinking by encouraging them to replace thoughts like "I have no choice" or "There's nothing I can do" with others that are more positive and optimistic. van Vegchel et al. (2004) suggested that task enrichment and decentralization of authority might be useful ways of providing employees that control. Developing teacher decisionmaking and problem-solving skills can make them feel more confident in their capacity of controlling events.

We herein propose several suggestions to continue studying this line of research in the future. Firstly, further research is needed to investigate the major needs of teachers in the workplace at other level of education and for teachers from other countries. Secondly, and based on The Job Demands and Resources Model of work engagement (JD-R) (Bakker \& Demerouti, 2007, 2008), it would be interesting to examine the role played by teaching needs in the motivational process suggested in this proposal. In this sense, we encourage research into the relationship among job resources, teacher needs and work engagement. Thirdly, it seems that unmet or unsatisfied psychological needs provoke negative consequences in human beings, which may affect their health and efficacy at work (Gold \& Roth 2005). Thus, it would also be recommendable to examine the influence that teacher needs may have on stress and burnout.

\section{References}

Aiken L. S., \& West S. G. (1991). Multiple regression: Testing and interpretation interactions. Newbury Park, CA: Sage.

Bakker A. B., \& Demerouti E. (2007). The job demandsresources model: State of the art. Journal of Managerial Psychology, 22, 309-328. http://dx.doi.org/10.1108/ 02683940710733115 
Bakker A. B., \& Demerouti E. (2008). Towards a model of work engagement. Career Development International, 13, 209-223. http:/ / dx.doi.org/10.1108/13620430810870476

Bentler P. M. (2006). EQS Structural equations program manual. Encino, CA: Multivariate Software.

Baumeister R. F., \& Leary M. R. (1995). The need to belong: Desire for interpersonal attachments as a fundamental human motivation. Psychological Bulletin, 117, 497-529. http:/ / dx.doi.org/10.1037/0033-2909.117.3.497

Bess J. L. (1977). The motivation of teach. The Journal of Higher Education, 48, 243-258. http:/ /dx.doi.org/ $10.2307 / 1978679$

Deci E., \& Ryan R. (1985). Intrinsic motivation and selfdetermination in human behavior. New York, NY: Plenum.

Deci E., \& Ryan R. (2000). The "what" and "why" of goal pursuits: Human needs and the self-determination of behavior. Psychological Inquiry, 11, 227-268. http:/ / dx.doi. org/10.1207/S15327965PLI1104_01

Deci E. L., \& Ryan R. M. (2002). Handbook of self-determination research. Rochester, NY: The University of Rochester Press.

Demerouti E., Bakker A. B., Janssen P. P. M., \& Schaufeli W. B. (2001). Burnout and engagement at work as a function of demands and control. Scandinavian Journal of Work, Environment \& Health, 27, 279-286. http:/ /dx.doi.org/ $10.5271 /$ sjweh.615

Durán A., Extremera N., \& Rey L. (2004). Engagement and burnout: Analyzing their association patterns. Psychological Reports, 94, 1048-1050.

Farber B. A. (1991). Crisis in education: Stress and burnout in the American teacher. San Francisco, CA: Jossey-Bass.

Fernet C., Senecal C., Guay F., Marsh H., \& Dowson M. (2008). The work task motivation scale for teachers. Journal of Career Assessment, 16, 256-279. http:/ / dx.doi.org/ $10.1177 / 1069072707305764$

Filak V. F., \& Sheldon K. M. (2003). Student psychological need satisfaction and college teacher-course evaluation. Educational Psychology, 23, 235-247. http:/ /dx.doi.org/ $10.1080 / 0144341032000060084$

Gagné M., \& Deci E. L. (2005). Self-determination theory and work motivation. Journal of Organizational Behavior, 26, 331-362. http://dx.doi.org/10.1002/job.322

Ganster D. G., \& Fusilier M. R. (1989). Control in the workplace. In C. L. Cooper \& I. T. Robertson (Eds.), International review of industrial and organizational psychology, (pp. 235-280). Chichester, UK: Wiley.

Gold Y., \& Roth R. A. (2005). Teachers managing stress and preventing burnout: The professional health solution ( $2^{\text {nd }} \mathrm{ed}$.). London, UK: The Palmer Press.

Hackman J. R., \& Oldham G. R. (1980). Work redesign. Reading, MA: Addison-Wesley.

Halbesleben J. R. B., \& Wheeler A. R. (2008). The relative roles of engagement and embeddedness in predicting job performance and intention to leave. Work and Stress, 22, 242-256. http:/ / dx.doi.org/10.1080/ 02678370802383962

Herzberg F. (1966). Work and the nature of man. Cleveland, OH: World.

Hobfoll S. E., Jonson R. J., Ennis N., \& Jackson A. P. (2003). Resource loss, resource gain and emotional outcomes among inner city women. Journal of Personality and Social
Psychology, 84, 632-643. http:/ / dx.doi.org/10.1037/00223514.84.3.632

Jesus S. N., \& Lens W. (2005). An integrated model for the study of teacher motivation. Applied Psychology: An International Review, 54, 119-134.

Kobasa S. G., Maddi S. R., \& Kahn S. (1982). Hardiness and health: A prospective study. Journal of Personality and Social Psychology, 42, 168-177. http:/ / dx.doi.org/10.1037/ /00223514.42.1.168

Kyriacou C. (1987). Teacher stress and burnout: An international review. Educational Research, 29, 146-152. http:/ /dx.doi.org/10.1080/0013188870290207

Lorente L., Salanova M., Martínez I., \& Schaufeli W. (2008). Extension of the job Demands-Resources model in the prediction of burnout and engagement among teachers over time. Psicothema, 20, 354-360.

Maslow A. (1954). Motivation and personality. New York, NY: Harper \& Row

Maslow A. (1972). Existence, relatedness and growth: Human needs in organizational setting. New York, NY: The Free Press.

Näring G., Briet M., \& Brouwers A. (2006). Beyond demand-control: Emotional labor and symptoms of burnout in teachers. Work and Stress, 20, 303-315.

Nunnaly J. C., \& Berstein I. H. (1994). Psychometric theory ( $3^{\text {rd }}$ ed.). New York, NY: McGraw-Hill.

Reis H., Sheldon K., Gable S., Roscoe J., \& Ryan R. (2000). Daily well-being: The role of autonomy, competence and relatedness. Personality and Social Psychology Bulletin, 26, 419-435. http:/ /dx.doi.org/10.1177/0146167200266002

Rotter J. B. (1954). Social learning and clinical psychology. New York, NY: Prentice-Hall.

Rotter J. B. (1966). Generalized expectancies for internal versus external control of reinforcement. Psychological Monographs: General and Applied, 80, 1-28. http://dx.doi. org/10.1037/h0092976

Salanova M., Agut S., \& Peiró J. M. (2005). Linking organizational resources and work engagement to employee performance and customer loyalty: The mediation of service climate. Journal of Applied Psychology, 90, 1217-1227. http://dx.doi.org/10.1037/00219010.90.6.1217

Schaufeli W. B., \& Bakker A. B. (2003). UWES-Utrecht Work Engagement Scale: Test manual. Utrech University, Utrech, The Netherlands.

Schaufeli W. B., \& Bakker A. B. (2004). Job demands, job resources and their relationship with burnout and engagement: A multi-sample study. Journal of Organizational Behavior, 25, 293-315. http:/ /dx.doi.org/ 10.1002/job.248

Schaufeli W. B., Salanova M., González-Romá V., \& Bakker A. B. (2002). The measurement of engagement and burnout: A two simple confirmation factor analytic approach. Journal of Happiness Studies, 3, 71-92.

Schaufeli W. B., Taris T. W., \& Bakker A. B. (2006). Dr Jeckyll or Mr Hyde: On the differences between work engagement and workaholism. In R. J. Burke (Ed.), Research companion to working time and work addiction. Cheltenham Glos, UK: Edward Elgar.

Scott C., Cox S., \& Dinham S. (1999). The occupational motivation, satisfaction and health of English school teachers. 
Educational Psychology, 19, 287-308. http:/ /dx.doi.org/ 10.1080/0144341990190304

Seligman M. E. P., \& Csikszentmihalyi M. (2000). Positive psychology: An introduction. American Psychologist, 55, 5-14. http:/ / dx.doi.org/10.1037/ /0003-066X.55.1.5

Sheldon K. M., Elliot A. J., Kim Y., \& Kasser T. (2001). What's satisfying about satisfying events? Comparing ten candidate psychological needs. Journal of Personality and Social Psychology, 80, 325-339.

Sheldon K., Ryan R., \& Reis H. (1996). What makes for a good day? Competence and autonomy in the day and in the person. Personality and Social Psychology Bulletin, 22, 1270-1279. http:/ /dx.doi.org/10.1177/01461672962212007 Spector P. E. (1982). Behavior in organizations as a function of employee's locus of control. Psychological Bulletin, 91, 482-497. http:/ /dx.doi.org/10.1037/ / 0033-2909.91.3.482

Spector P. E. (1988). Development of the Work Locus of Control Scale. Journal of Occupational Psychology, 61, 335-340. http:/ /dx.doi.org/10.1111/j.2044-8325.1988.tb00470.x

Spector P. E., \& O'Gonnell B. J. (1994). The contribution of personality traits, negative affectivity, locus of control and Type A to the subsequent reports of job stressors and job strains. Journal of Occupational and Organizational Psychology, 67, 1-12. http://dx.doi.org/10.1111/ j.2044-8325.1994.tb00545.x
Spector P. E., Cooper C. L., Sanchez J. I., O’Driscoll M., \& Sparks K. (2002). Locus of control and well-being at work: How generalizable are western findings? Academy of Management Journal, 45, 453-466. http:/ /dx.doi.org/ $10.2307 / 3069359$

Stockard J., \& Lehman M. B. (2004). Influences on the satisfaction and retention of 1st-year teachers: The importance of effective school management. Educational Administration Quarterly, 40, 742-771. http://dx.doi. org/10.1177/0013161X04268844

van den Broeck A., Vansteenkiste M., De Witte H., \& Lens W. (2008). Explaining the relationship between job characteristics, burnout, and engagement: The role of basic psychological need satisfaction. Work \& Stress, 22, 277-294. http:/ / dx.doi.org/10.1080/02678370802393672

van Vegchel N., De Jonge J., Soderfeldt M., Dormann C., \& Schaufeli W. (2004). Quantitative versus emotional demands among Swedish human service employees: Moderating effects of job control and social support. International Journal of Stress Management, 11, 21-40. http:/ /dx.doi.org/10.1037/1072-5245.11.1.21

Xanthopoulou D., Bakker A., Demerouti E., \& Schaufeli W. (2007). The role of personal resources in the job demandsresources model. International Journal of Stress Management, 14, 121-141. http:/ / dx.doi.org/10.1037/1072-5245.14.2.121 